\title{
Systematic Review \\ Oral Proliferative Verrucous Leukoplakia: Progression to Malignancy and Clinical Implications. Systematic Review and Meta-Analysis
}

\author{
Gaspare Palaia ${ }^{1}$, Amelia Bellisario ${ }^{1, *}$ (D) Riccardo Pampena ${ }^{2}$, Roberto Pippi ${ }^{1}$ and Umberto Romeo ${ }^{1}$ (I) \\ 1 Department of Oral and Maxillofacial Sciences, "Sapienza" University of Rome, Via Caserta 6, \\ 00161 Rome, Italy; gaspare.palaia@uniroma1.it (G.P.); roberto.pippi@uniroma1.it (R.P.); \\ umberto.romeo@uniroma1.it (U.R.) \\ 2 Centro Oncologico ad Alta Tecnologia Diagnostica, Azienda Unità Sanitaria Locale—IRCCS di Reggio Emilia, \\ 42123 Reggio Emilia, Italy; riccardo.pampena@ausl.re.it \\ * Correspondence: amelia.bellisario@virgilio.it
}

check for

updates

Citation: Palaia, G.; Bellisario, A.; Pampena, R.; Pippi, R.; Romeo, U. Oral Proliferative Verrucous Leukoplakia: Progression to Malignancy and Clinical Implications. Systematic Review and Meta-Analysis. Cancers 2021, 13, 4085. https://doi.org/10.3390/

cancers13164085

Academic Editor: David Wong

Received: 5 July 2021

Accepted: 11 August 2021

Published: 13 August 2021

Publisher's Note: MDPI stays neutral with regard to jurisdictional claims in published maps and institutional affiliations.

Copyright: (c) 2021 by the authors. Licensee MDPI, Basel, Switzerland. This article is an open access article distributed under the terms and conditions of the Creative Commons Attribution (CC BY) license (https:// creativecommons.org/licenses/by/ $4.0 /)$.
Simple Summary: Proliferative verrucous leukoplakia (PVL) was recognized in 2005 by the World Health Organization as a rare subtype of true oral leukoplakia, with unknown etiology. Since its first description in 1985, several diagnostic criteria have been proposed over the years. The aim of this systematic review is to investigate the percentage of patients diagnosed with proliferative verrucous leukoplakia who progressed to oral verrucous carcinoma (OVC) or conventional oral squamous cell carcinoma (OSCC).

Abstract: Aim: The aim of the present systematic review was to investigate the risk of malignant transformation of proliferative verrucous leukoplakia (PVL). Materials and Methods: the search was carried out using a combination of terms (leukoplakia OR leucoplakia) AND (multifocal OR proliferative) on the following databases: PubMed, Scopus, Web of Science (WOS Core Collection), Cochrane Library, selecting only articles published since 1985 and in the English language. Demographic, disease-related, and follow-up data extracted from the studies included in the qualitative synthesis were combined. Weighted means \pm standard deviations were calculated for continuous variables, while categorical variables were reported as frequencies and percentages. Dichotomous outcomes were expressed as odd ratios (ORs) with 95\% confidence intervals (CIs). Odd ratios for individual studies were combined using a random-effects meta-analysis, conducted using Review Manager 5.4 Software (Cochrane Community, Oxford, England). Results: twenty-two articles were included, with a total of 699 PVL patients, undergoing a mean follow-up of 7.2 years. Sixty-six percent of patients were females, with a mean age of 70.2 years, and $33.3 \%$ were males, with a mean age of 59.6 years. Most patients were non-smokers and non-alcohol users, and the gingiva/alveolar ridge mucosa was the most involved anatomical site by both PVL appearance and malignant transformation. A total of 320 PVL patients developed oral verrucous carcinoma (OVC) or conventional oral squamous cell carcinoma (OSCC) because of malignant transformation of PVL lesions (45.8\%). A statistically significant 3.8-fold higher risk of progression to conventional OSCC was found compared to OVC in PVL patients, with women being 1.7 times more likely to develop oral cancer than men, as a consequence of PVL progression. Moreover, a statistically significant higher likelihood of developing conventional OSCC in female PVL patients than in males was found. In $46.5 \%$ of patients with PVL malignant transformation, multiple carcinomas, in different oral sites, occurred during follow-up. Conclusions: PVL is an aggressive lesion, which, in a high percentage of cases (almost 50\%), undergoes malignant transformation, mainly toward OSCC. The female gender is most affected, especially in the elderly, with a negative history for alcohol and tobacco consumption.

Keywords: proliferative verrucous leukoplakia; oral cancer; biopsy 


\section{Introduction}

Proliferative verrucous leukoplakia (PVL) was recognized in 2005 by the World Health Organization (WHO) as a rare subtype of true oral leukoplakia, with unknown etiology, which mainly affects women in old age, often with a clinical history that does not include tobacco or alcohol consumption, with high risk of malignant transformation and diagnosis, usually retrospective, based on the association of clinical and histopathological aspects [1]

The expression "proliferative verrucous leukoplakia" was firstly introduced in literature in 1985 by Hansen et al. to define a lesion characterized mainly by multifocal presentation, exophytic and verruciform appearance, resistance to all therapeutic approaches, both surgical and non-surgical, high tendency to malignant transformation and progressive histological changes, evidenced in sequential biopsies, with evolution from simple hyperkeratosis, to lesions with increasing degrees of dysplasia, oral verrucous carcinoma (OVC), and conventional oral squamous cell carcinoma (OSCC) [2].

Several diagnostic criteria for PVL have been proposed over the years to help clinicians in diagnosis. In 2010, Cerero-Lapiedra et al. identified some major and minor criteria [3], which were then eliminated in 2013 by Carrard et al. [4].

Finally, in 2018, Villa et al. suggested that all the following criteria must be satisfied for a lesion to be classified as a PVL [5]:

(1) White/keratotic lesions that can be smooth, fissured, verrucous, or erythematous, with or without the presence of ulcerated areas.

(2) Non-contiguous multifocal lesions or single lesions larger than $4 \mathrm{~cm}$ in a single site or single lesions larger than $3 \mathrm{~cm}$ with the involvement of contiguous sites.

(3) Lesions that progress/expand and/or develop multifocality over time.

(4) Histopathology, which, in absence of dysplasia or carcinoma, still shows hyperkeratosis, parakeratosis, atrophy, or acanthosis with minimal or absent cytological atypia, with or without the presence of a lymphocytic band, or verrucous hyperplasia.

The most recent guidelines about the management of the proliferative verrucous leukoplakia include constant follow-up, every 3-6 months, with biopsies involving new onset red, or nodular areas, and areas of increased consistency [5].

Proliferative verrucous leukoplakia belongs to oral potentially malignant disorders [6] with the highest rate of neoplastic progression. Therefore, the aim of this review is to investigate the percentage of patients diagnosed with PVL who, over the years, underwent the development of OVC or OSCC.

\section{Materials and Methods}

A systematic review was conducted according to the Preferred Reporting Items for Systematic Reviews and Meta-Analyses (PRISMA) guidelines (Figure 1) and the MetaAnalysis of Observational Studies in Epidemiology (MOOSE) proposal when applicable. The protocol was registered on the international prospective register of systematic reviews (PROSPERO), with the reference number CRD42021229215.

The primary outcome was the ratio of PVL patients progressing to oral cancer (OSCC vs. OVC), while secondary outcomes included progression to cancer among genders.

The search was carried out using a combination of terms (leukoplakia OR leucoplakia) AND (multifocal OR proliferative) on the following databases:

- PubMed.

- Scopus.

- Web of Science (WOS Core Collection).

- Cochrane Library.

Only articles published in English from 1985 to 26 November, 2020, were selected. The inclusion criteria for articles to be included were:

- Studies involving at least 10 PVL patients.

- Diagnosis of PVL carried out on the basis of the criteria defined by Hansen et al. [2], or subsequent modifications. 
- Studies reporting the number of patients who, over time, developed oral cancer as a consequence of PVL neoplastic transformation.

- Articles in which the mean follow-up of PVL patients was explicitly reported.

The following sources were excluded from this review: other reviews, meeting abstracts, letters to the editor, book chapters (Figure 1).

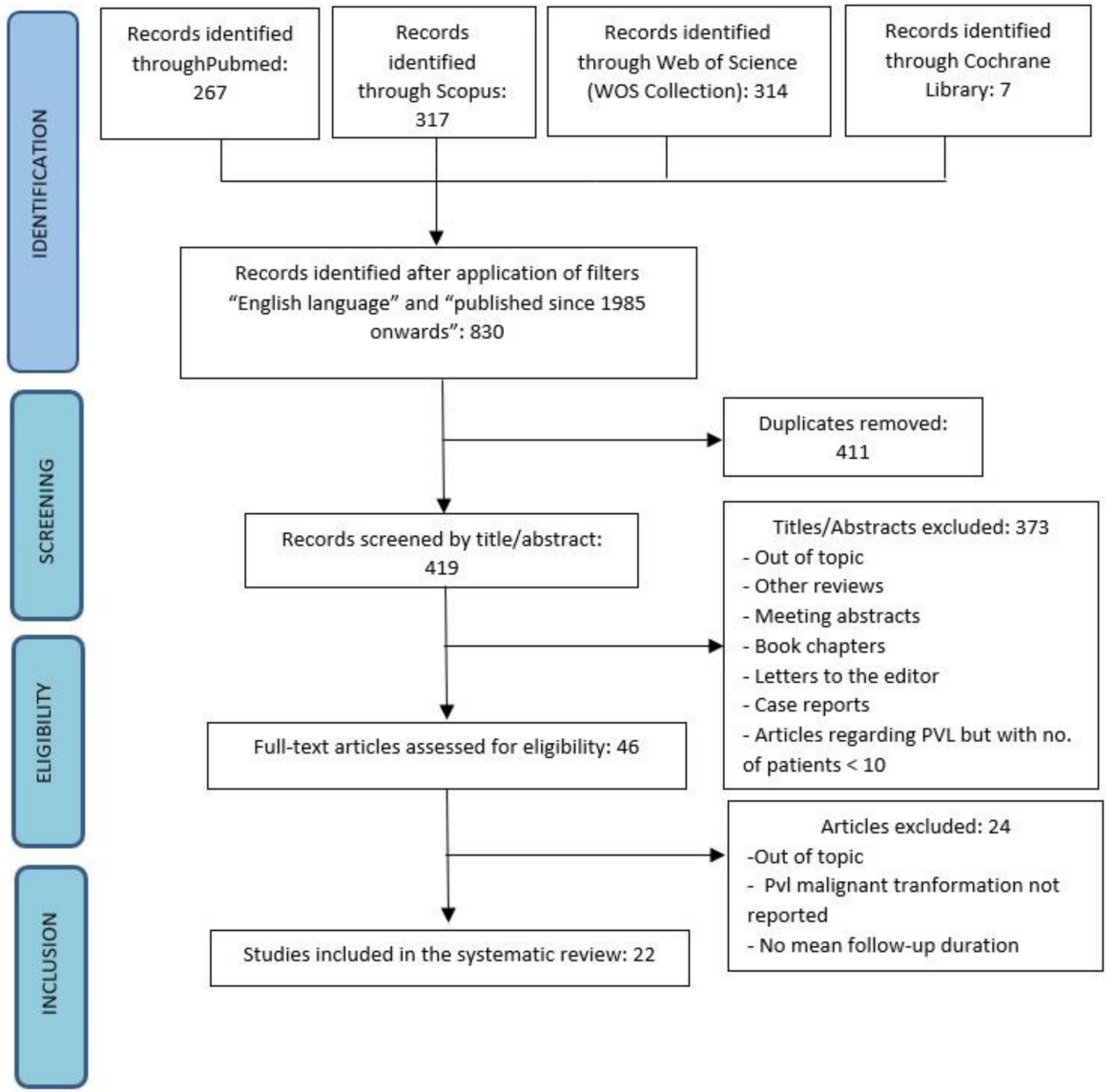

Figure 1. Flowchart of search results and study selection.

The literature search was performed independently by two researchers (A.B., R.P.) and, in case of disagreement, the intervention of a third researcher (G.P.) was requested.

During the article selection procedure, in case of suspicion of patients included in more than one study, an email was sent to the authors to receive detailed information; in case of a missing answer, or whether it was not possible to identify any duplicates, it was decided to include, in this review, only the most recent article with the greatest number of cases. At the end of the search procedure, 22 articles were included in this systematic review (Table 1).

Before proceeding with the processing of results, a table was created in Microsoft Excel, in which data obtained from individual studies were entered.

The information considered for each article included:

- First author;

- Year of publication;

- Country in which the study was conducted;

- Enrolment period of patients;

- $\quad$ Type of study with any statistical analysis applied;

- Number of patients with PVL diagnosis;

- Gender;

- Mean age; 
- Mean duration of follow-up;

- Current or past use of tobacco or alcohol;

- Number of patients who underwent neoplastic transformation of the lesion, including the number of men and women;

- Subjects who developed verrucous carcinoma or conventional oral squamous cell carcinoma (included gender);

- Number of patients who developed multiple carcinomas in different intraoral sites;

- Mean time from diagnosis of PVL to neoplastic transformation;

- Mean number of biopsies per patient;

- Mean time between first and eventual second primary oral carcinoma;

- Number of patients who died from causes related to oral carcinoma;

- The site most frequently involved by the onset of PVL or by malignant transformation.

Table 1. Studies included in this systematic review.

\begin{tabular}{|c|c|c|c|c|}
\hline Authors & Year of Publication & $\begin{array}{c}\text { Number of PVL } \\
\text { Patients }\end{array}$ & $\begin{array}{c}\text { Patients Enrolment } \\
\text { Period }\end{array}$ & Type of Study \\
\hline Hansen et al. [2] & 1985 & 30 & 1961-1983 & Retrospective case series \\
\hline Zakrzewska et al. [7] & 1996 & 10 & - & Case series \\
\hline Silverman e Gorsky [8] & 1997 & 54 & - & Case series \\
\hline Schoelch et al. [9] & 1999 & 12 & - & Case series \\
\hline Fettig et al. [10] & 2000 & 10 & 1995-1999 & Case series \\
\hline Bagan et al. [11] & 2003 & 30 & - & Case control \\
\hline Bagan et al. [12] & 2004 & 19 & - & Case series \\
\hline Gandolfo et al. [13] & 2009 & 47 & 1981-2006 & Retrospective case control \\
\hline Poveda-Roda et al. [14] & 2010 & 17 & - & Preliminary study \\
\hline Gouvea et al. [15] & 2013 & 21 & - & Retrospective case control \\
\hline Garcìa-Chìas et al. [16] & 2014 & 40 & 1984-2011 & Retrospective case series \\
\hline Flores et al. [17] & 2016 & 15 & - & Case control \\
\hline Garcìa-Pola et al. [18] & 2016 & 14 & 1984-2015 & $\begin{array}{l}\text { Observational descriptive } \\
\text { study }\end{array}$ \\
\hline Borgna et al. [19] & 2016 & 48 & 1990-2015 & Retrospective case series \\
\hline Thomson et al. [20] & 2018 & 80 & $1996-2014$ & Retrospective cohort \\
\hline Upadhyaya et al. [21] & 2018 & 20 & 1994-2016 & Retrospective case series \\
\hline Villa et al. [5] & 2018 & 42 & 1996-2016 & Retrospective case series \\
\hline Bagan et al. [22] & 2019 & 63 & 2003-2018 & $\begin{array}{l}\text { Retrospective observational } \\
\text { clinical study }\end{array}$ \\
\hline Koh et al. [23] & 2019 & 10 & - & Case control \\
\hline Favia et al. [24] & 2020 & 75 & 1989-2008 & Retrospective case series \\
\hline Llorens et al. [25] & 2020 & 10 & - & Retrospective case control \\
\hline $\begin{array}{c}\text { McParland and } \\
\text { Warnakulasuriya [26] }\end{array}$ & 2020 & 51 & - & Retrospective case series \\
\hline
\end{tabular}

Demographic, disease-related, and follow-up data extracted from the studies included in the qualitative synthesis were combined. Weighted means \pm standard deviations were calculated for continuous variables, while categorical variables were reported as frequencies and percentages.

Dichotomous outcomes were expressed as odd ratios (ORs) with $95 \%$ confidence intervals (CIs).

Odd ratios for individual studies were combined using a random-effects meta-analysis.

The meta-analysis was conducted using Review Manager 5.4 Software (Cochrane Community, Oxford, UK).

The evaluation of Recommendation and Quality of Evidence of included studies was conducted according to Robinson et al.'s assessment [27] (Table 2). 
Table 2. Evaluation of recommendation and quality of evidence of included studies according to Robinson et al. [27]. (2A: weak recommendation; limited quality, patient-oriented evidence. B: Systematic review/meta-analysis of lower quality cohort studies with inconsistent results that may vary depending on circumstances or patients or societal values; retrospective cohort studies; casecontrol study. C: Consensus guidelines, usual practice, expert opinion, case series; other alternatives may be equally reasonable).

\begin{tabular}{|c|c|c|c|}
\hline Authors & Year of Publication & $\begin{array}{c}\text { Grade of } \\
\text { Recommendation }\end{array}$ & $\begin{array}{l}\text { Quality of } \\
\text { Evidence }\end{array}$ \\
\hline Hansen et al. [2] & 1985 & $2 \mathrm{~A}$ & $\mathrm{C}$ \\
\hline Zakrzewska et al. [7] & 1996 & $2 \mathrm{~A}$ & $\mathrm{C}$ \\
\hline Silverman and Gorsky [8] & 1997 & $2 \mathrm{~A}$ & $\mathrm{C}$ \\
\hline Schoelch et al. [9] & 1999 & $2 \mathrm{~A}$ & $\mathrm{C}$ \\
\hline Fettig et al. [10] & 2000 & $2 \mathrm{~A}$ & $\mathrm{C}$ \\
\hline Bagan et al. [11] & 2003 & $2 \mathrm{~A}$ & $\mathrm{~B}$ \\
\hline Bagan et al. [12] & 2004 & $2 \mathrm{~A}$ & $\mathrm{C}$ \\
\hline Gandolfo et al. [13] & 2009 & $2 \mathrm{~A}$ & B \\
\hline Poveda-Roda et al. [14] & 2010 & $2 \mathrm{~A}$ & B \\
\hline Gouvea et al. [15] & 2013 & $2 \mathrm{~A}$ & B \\
\hline Garcìa-Chìas et al. [16] & 2014 & $2 \mathrm{~A}$ & $\mathrm{C}$ \\
\hline Flores et al. [17] & 2016 & $2 \mathrm{~A}$ & B \\
\hline Garcìa-Pola et al. [18] & 2016 & $2 \mathrm{~A}$ & $\mathrm{C}$ \\
\hline Borgna et al. [19] & 2016 & $2 \mathrm{~A}$ & $\mathrm{C}$ \\
\hline Thomson et al. [20] & 2018 & $2 \mathrm{~A}$ & B \\
\hline Upadhyaya et al. [21] & 2018 & $2 \mathrm{~A}$ & $\mathrm{C}$ \\
\hline Villa et al. [5] & 2018 & $2 \mathrm{~A}$ & $\mathrm{C}$ \\
\hline Bagan et al. [22] & 2019 & $2 \mathrm{~A}$ & $\mathrm{C}$ \\
\hline Koh et al. [23] & 2019 & $2 \mathrm{~A}$ & B \\
\hline Favia et al. [24] & 2020 & $2 \mathrm{~A}$ & $\mathrm{C}$ \\
\hline Llorens et al. [25] & 2020 & $2 \mathrm{~A}$ & B \\
\hline $\begin{array}{c}\text { McParland and } \\
\text { Warnakulasuriya [26] }\end{array}$ & 2020 & $2 \mathrm{~A}$ & C \\
\hline
\end{tabular}

\section{Results}

Twenty-two articles were included. One of them [12] referred to the same patient group reported by another [11], but provided data related to the development of multiple carcinomas (Table 1). Overall, the total number of patients with a diagnosis of PVL was 699. The mean age, reported in 19 studies, involving a total of 573 patients $[2,5,7-11,13-23,25]$, was $64.2 \pm 10.5$ years, while follow-up had a variable duration, from 3.3 to 16 years (mean value $7.2 \pm 6.3$ years) (Table 3 ).

The percentage of male and female subjects, reported in 20 articles [2,5,7-11,13-23,25,26], was, respectively, $33.3 \%$ (208 out of 624 ) and $66.7 \%$ (416 out of 624 ), with a mean age of 59.6 years for men and 70.2 years for women $[2,5,7,8,10,14,17,18,20,21,23,25,26]$ (Table 3).

There were 11 studies reporting the enrolment period of patients $[2,5,10,13,16,18-22,24]$, ranging from 4 to 31 years, with a mean value of approximately 20 years, and a range from 1985 to 2020, although in most articles, the type of enrolment (consecutive or nonconsecutive) was not reported.

Out of the 699 patients, 106 were from California (USA) [2,8-10], 189 from United Kingdom [7,19,20,26], 174 from Spain [11,14,16,18,22,25], 122 from Italy [13,24], 15 exclusively from Brazil [17], 21 from Brazil and Guatemala [15], 20 from Florida (USA) [21], 10 from Georgia (USA) [23] and 42 from Massachusetts (USA), New York State (USA), and Brazil [5].

Current or past tobacco use (smoked or chewed) was reported in 19 studies, for 218 out of 544 PVL patients $(40.0 \%)$ [2,5,7-11,13-19,21-23,25,26] (Table 3), while eight studies $[5,13,15,17-19,25,26]$ described the spread of consumption of alcohol, which turned out to be $26.2 \%$ ( 65 out of 248 PVL patients). 
Table 3. Data relating to the number of PVL patients, sex, tobacco consumption, mean follow-up, number of patients with neoplastic evolution of PVL and with development of multiple oral carcinomas.

\begin{tabular}{|c|c|c|c|c|c|c|c|}
\hline Authors & $\begin{array}{l}\text { Number of } \\
\text { PVL Patients }\end{array}$ & $\mathbf{M}$ & $\mathbf{F}$ & Tobacco Use & $\begin{array}{c}\text { Mean } \\
\text { Follow-Up } \\
(Y)\end{array}$ & $\begin{array}{l}\text { Number of PVL } \\
\text { Patients with } \\
\text { Malignant } \\
\text { Transformation }\end{array}$ & $\begin{array}{l}\text { Number of } \\
\text { Patients } \\
\text { with } \\
\text { Multiple } \\
\text { Oral Cancers }\end{array}$ \\
\hline Hansen 1985 [2] & 30 & 6 & 24 & 18 & 6.1 & $26 / 30$ & - \\
\hline Zakrzewska 1996 [7] & 10 & 5 & 5 & 7 & 6.6 & $10 / 10$ & - \\
\hline Silverman 1997 [8] & 54 & 11 & 43 & 17 & 11.6 & $38 / 54$ & $12 / 38$ \\
\hline Schoelch 1999 [9] & 12 & 4 & 8 & 5 & 4 & $2 / 12$ & - \\
\hline Fettig 2000 [10] & 10 & 6 & 4 & 3 & 4.4 & $6 / 10$ & - \\
\hline Bagan $2003 / 2004[11,12]$ & 30 & 6 & 24 & 7 & 4.7 & $27 / 30$ & $10 / 19$ \\
\hline Gandolfo 2009 [13] & 47 & 10 & 37 & 17 & 6.8 & $19 / 47$ & $8 / 19$ \\
\hline Poveda-Roda 2010 [14] & 17 & 7 & 10 & 6 & 6.6 & $5 / 17$ & $3 / 5$ \\
\hline Gouvea 2013 [15] & 21 & 3 & 18 & 4 & 7.3 & $9 / 21$ & $2 / 9$ \\
\hline Garcìa-Chìas 2014 [16] & 40 & 15 & 25 & 13 & 3.6 & $7 / 40$ & - \\
\hline Flores 2016 [17] & 15 & 0 & 15 & 0 & 5.4 & $4 / 15$ & $2 / 4$ \\
\hline Garcì-Pola 2016 [18] & 14 & 3 & 11 & 3 & 14.5 & $4 / 14$ & - \\
\hline Borgna 2016 [19] & 48 & 24 & 24 & 33 & 4.3 & $23 / 48$ & - \\
\hline Thomson 2018 [20] & 80 & 41 & 39 & - & 4 & $2 / 80$ & - \\
\hline Upadhyaya 2018 [21] & 20 & 6 & 14 & 12 & 7.6 & $9 / 20$ & $3 / 9$ \\
\hline Villa 2018 [5] & 42 & 7 & 35 & 17 & 4.5 & $30 / 42$ & $10 / 30$ \\
\hline Bagan 2019 [22] & 63 & 20 & 43 & 25 & 6 (median) & $30 / 63$ & - \\
\hline Koh 2019 [23] & 10 & 5 & 5 & 6 & 3.3 & $4 / 10$ & - \\
\hline Favia $2020[24]$ & 75 & - & - & - & 5.2 (median) & $48 / 75$ & $33 / 48$ \\
\hline Llorens 2020 [25] & 10 & 4 & 6 & 3 & 12.2 & $6 / 10$ & $4 / 6$ \\
\hline McParland 2020 [26] & 51 & 25 & 26 & 22 & 16 & $11 / 51$ & - \\
\hline Total & 699 & 208 & 416 & $218 / 544$ & 7.2 & $320 / 699$ & $87 / 187$ \\
\hline
\end{tabular}

Avoiding considering the studies that selected only PVLs with gingival localization $[10,22]$, there were 16 articles which reported the lesion site $[2,5,7,8,11,13,15-21,23,25,26]$. The most involved site was the gingiva/alveolar ridge mucosa, followed, in equal measure, by the tongue and the buccal mucosa, and finally the vestibule.

The number of patients undergoing PVL malignant transformation during the followup, with the development of at least one oral carcinoma, was 320 (45.8\%; Table 3).

A statistically significant difference was found in the probability for female vs. male patients to undergo malignant transformation of PVL, with women being 1.7 times more likely to develop cancer as a consequence of PVL progression than men (OR 0.57, 95\% CI 0.35-0.93) (Figure 2).

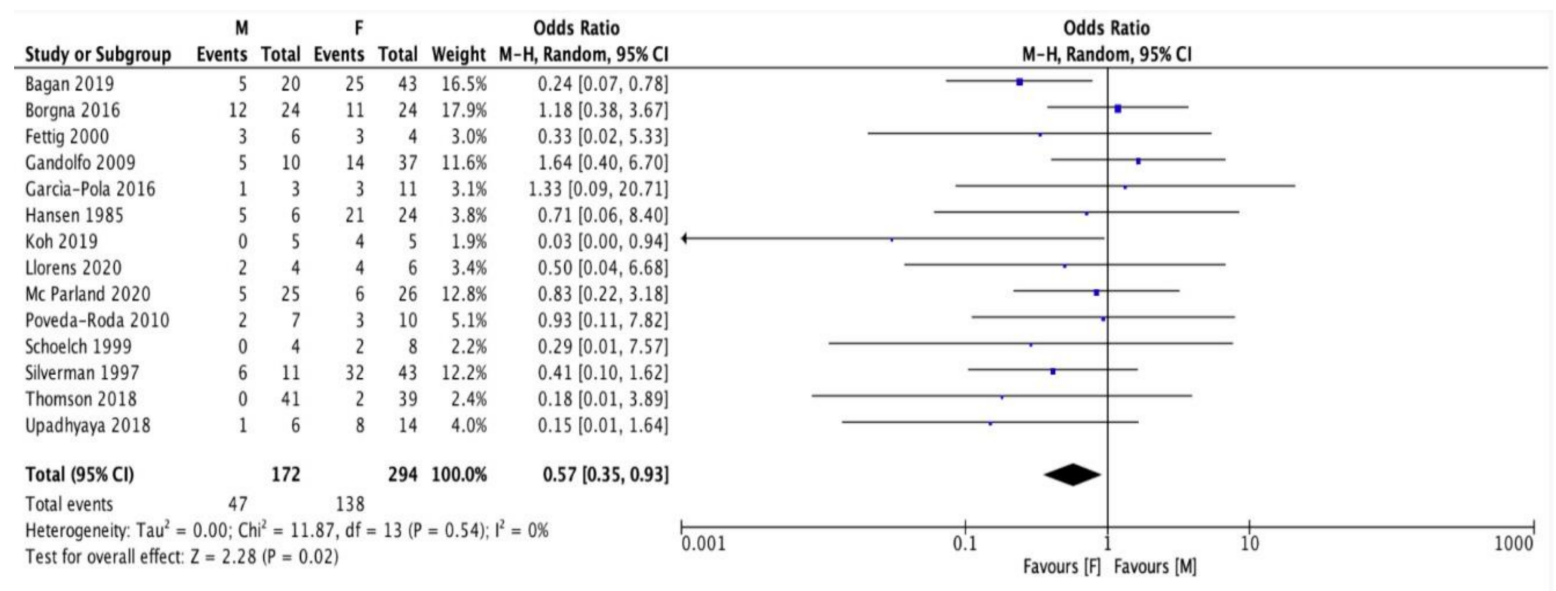

Figure 2. Forest plot relating to the prevalence of neoplastic events in male (M) and female (F) patients. 
In addition, a statistically significant 3.8-fold higher risk of progression to conventional squamous cell carcinoma (OSCC) compared to verrucous carcinoma (OVC) was found in PVL patients (OR 3.75, 95\% CI 1.75-8.06) (Figure 3).

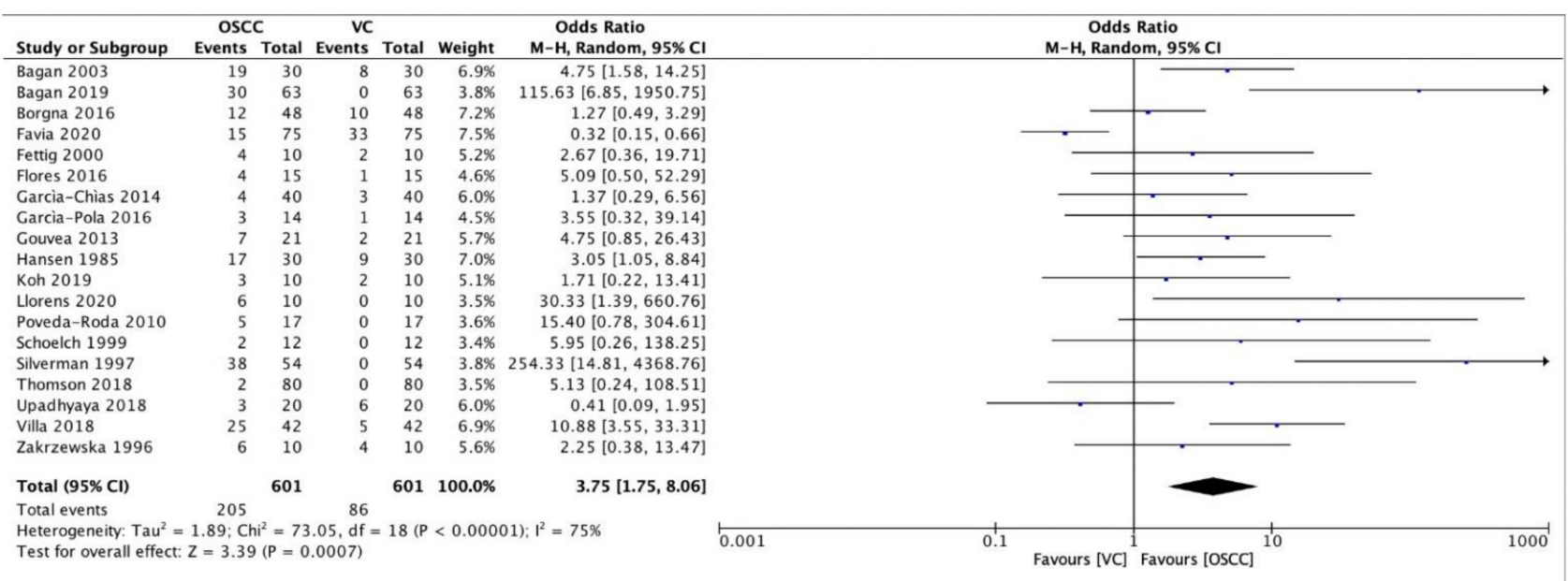

Figure 3. Forest plot relating to the distribution of conventional oral squamous cell carcinomas (OSCC) and verrucous carcinomas (VC) among patients with PVL.

The likelihood of developing OSCC was found to be approximately three times higher in female PVL patients than in male PVL patients, which was statistically significant (OR 0.33, 95\% CI 0.18-0.59) (Figure 4).

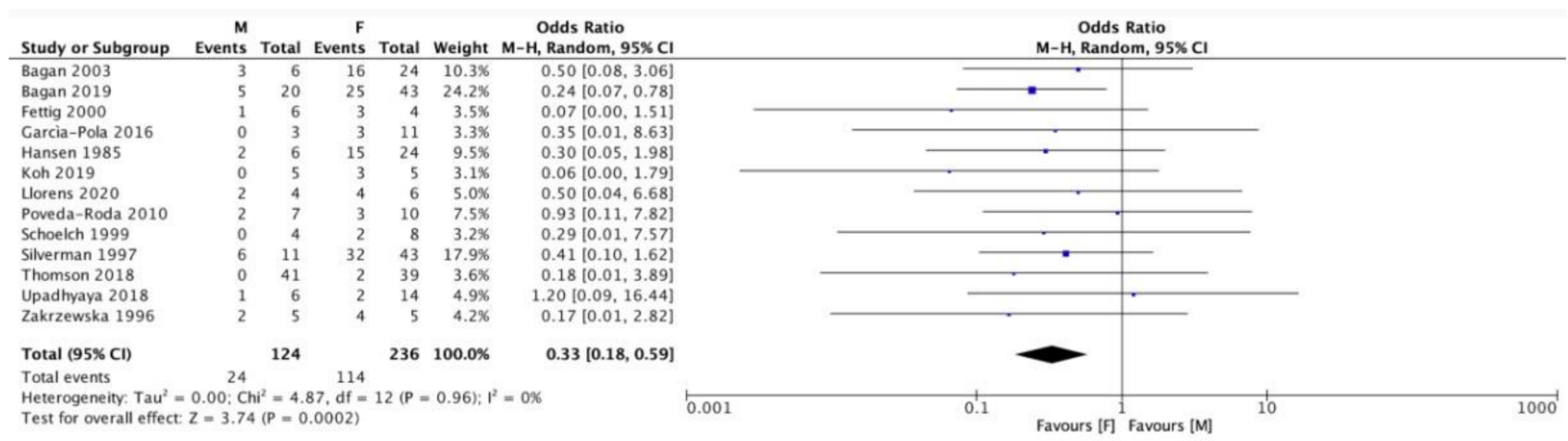

Figure 4. Forest plot relating to the distribution of conventional oral squamous cell carcinomas (OSCC) in male (M) and female $(\mathrm{F})$ patients.

On the other hand, it seemed that the development of an OVC was more likely in men than in women, even if in this case no statistical significance was found (Figure 5).



Figure 5. Forest plot relating to the distribution or oral verrucous carcinomas (OVC) in male (M) and female (F) patients. 
There were 12 articles that reported the time elapsed between the diagnosis of PVL and its malignant transformation, with a mean value of 4.1 years [5,8-11,13,16,18,19,21,22,25].

In 87 out of a total of 187 patients with malignant transformation of PVL $(46.5 \%$; Table 3) $[5,8,12-15,17,21,24,25]$, multiple carcinomas were diagnosed in different oral sites during the follow-up.

Only three studies revealed the average time elapsed between the development of the first and a possible second primary cancer, with values of 1.6 [11], 1.81 [13], and 1.5 [24] years.

The mean duration of follow-up for PVL patients without malignant transformation was 5.8 years; for those with malignant transformation, it was 8.3 years $[2,5,13,17,19,21,23,25]$.

Regarding the most involved site by malignant transformation, excluding studies selecting only gingival PVLs [10,22], in seven studies, the gingiva/alveolar ridge mucosa was the most frequently affected site $[8,12,13,18,21,24,25]$.

Six studies, for a total of 160 subjects, provided information about the number of biopsies performed in each patient, with a mean value of 7.5 biopsies per patient $[2,5,7,19,21,23]$.

Regarding the survival of PVL patients during follow-up, data related to patients who died because of the development of one or more oral cancers from a pre-existing PVL was provided by nine studies: $40 \%$ of patients with a mean follow-up of 6.1 years [2], 20\% with a mean follow-up of 6.6 years [7], 38.9\% with a mean follow-up of 11.6 years [8], 10\% with a mean follow-up of 4.4 years [10], 5.2\% with a mean follow-up of 5.1 years [12], $0 \%$ with a mean follow-up of 5.4 years [17], 14.3\% with a mean follow-up of 14.5 years [18], 12.5\% with a mean follow-up of 4.3 years [19], and 5.3\% with a median follow-up of 5.2 years [24].

Combining the information provided by the various studies, 49 out of 286 patients died as a consequence of oral cancer developed from PVL (17.1\%).

Concerning quality assessment, all of the included studies were evaluated as reporting weak recommendation and limited-quality, patient-oriented evidence, independently from the study design (case series, cohort, case-control). The low quality of evidence on this topic, amplifies the need for a meta-analysis as well as for further prospective studies.

\section{Discussion}

In regard to sex distribution of PVL, according to the literature [28-30], women were involved by PVL more $(416=66.7 \%)$ than men, especially in old age (mean age: 70.2 years). The gingiva/alveolar ridge mucosa was found to be the most involved intraoral site by both PVL and its malignant transformation. Usually, the lesion first involves the gingiva of a single tooth, often buccally, and then extends, over time, to that of the adjacent teeth, also on the lingual and palatal sides, likely involving the interdental periodontal tissues [5]. Therefore, any gingival leukoplakia, which progressively involves other anatomical sites over the years, must be viewed with suspicion. McParland and Warnakulasuriya in 2020 reported that 19 of the 51 patients with PVL had gingival lesions at the time of the disease onset $(37.2 \%)$, while, at the last follow-up, gingival involvement was found in 33 out of the 51 patients $(64.7 \%)$. Similarly, among patients who underwent neoplastic evolution of PVL, most cancers arose at the gingival level [26]. Bagan et al. in 2011, in a retrospective study on 55 subjects with PVL, found that the gingiva was the most frequently involved site by PVL ( $89.1 \%$ of cases), and that more than $50 \%$ of the OSCC developed from gingival lesions [31]. Silverman and Gorsky also reported that PVLs of the gingiva, as well as those of the tongue, had a higher tendency to malignant transformation $(p=0.13)$, compared to those of all other oral sites [8].

Regarding the recurrence of gingival PVL, Villa et al. [5] hypothesized that it was correlated not only to clinical features, but also to a possible incomplete excision of pathological tissue, at the level of crevicular epithelium, which therefore was able to repopulate the biopsied area, leading to the progression of residual pathological cells, rather than to a real recurrence. There are only two studies describing the tongue as the most affected site of PVL malignant transformation $[15,17]$. 
The percentage of patients with malignant transformation of PVL, in the selected studies, varied from $2.5 \%$ to $100 \%$, with a mean value of $45.8 \%$ (320 out of 699 subjects), and a mean follow-up of 7.2 years.

Women have a significantly higher risk of developing cancer from a previous PVL than men (OR 0.57, 95\% CI 0.35-0.93), even considering the higher incidence of PVL in females. Only Borgna et al. [19] found a slight opposite prevalence between men and women (12:11) among PVL-related cancer patients.

In the present review, a statistically higher risk of PVL transformation to OSCC rather than OVC was found, with articles by Favia et al. [24] and Upadhyaya et al. [21] being the only exceptions. However, the risk that a patient with PVL may develop verrucous carcinoma is still higher than in the general population since the prevalence of oral verrucous carcinoma varies from $2 \%$ to $12 \%$ [32,33], while the present study found a $29.5 \%$ prevalence $(86 / 291)$ in PVL patients.

It was also found that females not only have a higher incidence of PVL with an increased risk of its malignant transformation, but they also have a statistically higher risk of PVL progression to OSCC than males.

On the other hand, the occurrence of a verrucous carcinoma seems to be more likely in men, although with no statistical significance; thus, males, in addition to being less affected by both PVL and its malignant transformation, seem to be more frequently involved by OVC rather than OSCC, which has a much lower aggressiveness than OSCC [34], although further investigation is needed to verify this datum.

It is worthy of note that patients with PVL who develop an oral cancer, in $46.5 \%$ of cases develop at least one second tumor in a different intraoral site. In this regard, Bagan et al. [35] published a retrospective comparative study between a group of 33 patients with two or more PVL-related OSCC and a group with 48 no-cancer PVL patients, and found that clinical factors associated with the possibility of belonging to group 1 were a longer follow-up and a greater number of PVL-affected oral sites. Furthermore, the time interval between the diagnosis of each carcinoma and the next was, each time, shorter, and the most involved anatomical site by the first four carcinomas was gingiva, while buccal mucosa or the tongue were more frequently involved by the fifth new carcinoma [35].

The multifocal presentation typical of PVL and the high risk of developing multiple primary oral carcinomas have been associated with the concept of field cancerization, proposed in 1953 by Slaughter et al. [36], and subsequently suggested by others [37,38], to explain the occurrence of more than one carcinoma in the same district. This theory argues that there is the presence of genetically mutated cells even beyond the area with alterations evident on clinical or histopathological examination and the main molecular alterations would involve mutations in oncogenes or tumor suppressor genes, genomic instability and loss of heterozygosity. In the case of the upper aero digestive tract, these alterations have usually been correlated with prolonged exposure to carcinogens, such as tobacco; however, since most patients with PVL are not tobacco users [2,8], probably further, but yet unidentified, mechanisms may be involved. In this regard HPV infection has also been suggested having a role both in PVL etiopathogenesis and in its malignant transformation $[39,40]$. Moreover, PVL has different demographic aspects than those of conventional true oral leukoplakia [28] and, frequently, a verrucous appearance, which is typical of HPV-related lesions. However, other authors did not find any statistical correlation between HPV infection and both PVL [41,42] and its progression to malignancies [21]; therefore, it is not possible to exclude or confirm a possible etiopathogenetic role of HPV.

The consumption of tobacco (smoked or chewed) and alcohol does not seem to play an important role in the onset of this lesion, differently from the true leukoplakia, for which tobacco is recognized as the only risk factor [43]. Collecting data from the individual studies analyzed, a current or previous tobacco consumption was found in 218 out of 544 patients with PVL (40\%), and alcohol use in 65 out of 248 subjects $(26.2 \%)$. In five studies, the number of tobacco users exceeded half of the analyzed subjects $[2,7,19,21,23]$. Moreover a significant number of patients with PVL malignant transformation were not 
smokers; Bagan et al. in 2003 reported the presence of 4 tobacco users among 19 with PVL and progression to OSCC (21.1\%) and 78 among 110 patients with OSCC not preceded by PVL lesions (70.9\%) [11]. Favia et al., described the presence of 11 smoking patients among 48 with PVL who developed at least one carcinoma (22.9\%) [24]. Borgna et al., in 2016, found no significant differences regarding tobacco and alcohol use between the 23 patients with PVL and malignant transformation and the 25 individuals with PVL without malignant transformation [19].

As for the etiopathogenesis of PVL-related carcinomas-in 2015, Akrish et al. hypothesized [44] that PVL-related OSCC represented a distinct entity with respect to PVLunrelated OSCC since many features differed in the two conditions. They found PVLrelated OSCC being more frequently featured by the following features: early stage of development, small tumor size, no lymph node metastases, gingiva and buccal location, local relapses or second primary tumor, and a good 4-year survival rate (100\%). On the contrary, PVL-unrelated OSCC were featured by the following features: more advanced stage of development with wider tumor size, high frequency of lymph node metastases (36.7\%), lingual margin and mouth floor mucosa as prevalent locations, less frequent relapses or second tumors $(12.2 \%)$. This hypothesis, obviously, may have practical implications in choosing both treatment strategies and follow-up timing for OSSCs occurring in the two different conditions, although further comparative studies with wider sample sizes are needed to corroborate such a suggested point of view.

\section{Conclusions}

According to the results of this systematic review, it can be stated that PVL is an aggressive lesion, which, in almost $50 \%$ of cases, undergoes malignant transformation, mainly toward OSCC. Women are more involved than men, especially in older age and with a negative history of alcohol and tobacco consumption.

Early diagnosis and constant surveillance with periodic biopsies are of paramount importance in management of PVL patients, especially when an oral carcinoma has already developed.

Author Contributions: Conceptualization, G.P., A.B., R.P. (Roberto Pippi), U.R.; methodology, A.B., R.P. (Riccardo Pampena); software, R.P. (Riccardo Pampena); validation, G.P., A.B., R.P. (Riccardo Pampena), R.P. (Roberto Pippi), U.R.; formal analysis, G.P.; investigation, A.B., R.P. (Riccardo Pampena); resources, R.P. (Roberto Pippi); data curation, U.R.; writing - original draft preparation, G.P., A.B., R.P. (Riccardo Pampena); writing—review and editing, R.P. (Roberto Pippi), U.R.; visualization, G.P.; supervision, R.P. (Roberto Pippi); project administration, U.R. All authors have read and agreed to the published version of the manuscript.

Funding: This research received no external funding.

Conflicts of Interest: The authors declare no conflict of interest.

\section{References}

1. Warnakulasuriya, S.; Kujan, O.; Aguirre-Urizar, J.M.; Bagan, J.V.; González-Moles, M.; Kerr, A.R.; Lodi, G.; Mello, F.W.; Monteiro, L.; Ogden, G.R.; et al. Oral potentially malignant disorders: A consensus report from an international seminar on nomenclature and classification, convened by the WHO Collaborating Centre for Oral Cancer. Oral Dis. 2020. [CrossRef]

2. Hansen, L.S.; Olson, J.A.; Silverman, S., Jr. Proliferative verrucous leukoplakia: A long-term study of thirty patients. Oral Surg. Oral Med. Oral Pathol. 1985, 60, 285-298. [CrossRef]

3. Cerero-Lapiedra, R.; Balade-Martinez, D.; Moreno-López, L.A.; Esparza-Gomez, G.; Bagan, J. Proliferative verrucous leukoplakia: A proposal for diagnostic criteria. Med. Oral Patol. Oral Cir. Bucal 2010, 15, e839-e845. [CrossRef] [PubMed]

4. Carrard, V.C.; Brouns, E.R.; van der Waal, I. Proliferative verrucous leukoplakia; a critical appraisal of the diagnostic criteria. Med. Oral Patol. Oral Cir. Bucal 2013, 18, e411-e413. [CrossRef]

5. Villa, A.; Menon, R.S.; Kerr, A.R.; De Abreu, A.F.; Guollo, A.; Ojeda, D.; Woo, S.B. Proliferative leukoplakia: Proposed new clinical diagnostic criteria. Oral Dis. 2018, 24, 749-760. [CrossRef]

6. Gupta, S.; Jawanda, M.K.; Madhushankari, G.S. Current challenges and the diagnostic pitfalls in the grading of epithelial dysplasia in oral potentially malignant disorders: A review. J. Oral Biol. Craniofac. Res. 2020, 10, 788-799. [CrossRef] [PubMed] 
7. Jacobson, J.; Van Dis, M.; Zakrzewska, J.; Lopes, V.; Speight, P.; Hopper, C. Proliferative verrucous leukoplakia: A report of ten cases. Oral Surg. Oral Med. Oral Pathol. Oral Radiol. Endodontol. 1996, 82, 396-401. [CrossRef]

8. Silverman, S., Jr.; Gorsky, M. Proliferative verrucous leukoplakia: A follow-up study of 54 cases. Oral Surg. Oral Med. Oral Pathol. Oral Radiol. Endodontol. 1997, 84, 154-157. [CrossRef]

9. Schoelch, M.L.; Sekandari, N.; Regezi, J.A.; Silverman, S., Jr. Laser management of oral leukoplakias: A follow-up study of 70 patients. Laryngoscope 1999, 109, 949-953. [CrossRef]

10. Fettig, A.; Pogrel, M.A.; Silverman, S., Jr.; Bramanti, T.E.; Da Costa, M.; Regezi, J.A. Proliferative verrucous leukoplakia of the gingiva. Oral Surg. Oral Med. Oral Pathol. Oral Radiol. Endodontol. 2000, 90, 723-730. [CrossRef]

11. Bagan, J.V.; Jimenez, Y.; Sanchis, J.M.; Poveda, R.; Milian, M.A.; Murillo, J.; Scully, C. Proliferative verrucous leukoplakia: High incidence of gingival squamous cell carci-noma. J. Oral Pathol. Med. 2003, 32, 379-382. [CrossRef]

12. Bagán, J.V.; Murillo, J.; Poveda, R.; Gavaldá, C.; Jiménez, Y.; Scully, C. Proliferative verrucous leukoplakia: Unusual locations of oral squamous cell carcinomas, and field cancerization as shown by the appearance of multiple OSCCs. Oral Oncol. 2004, 40, 440-443. [CrossRef]

13. Gandolfo, S.; Castellani, R.; Pentenero, M. Proliferative verrucous leukoplakia: A potentially malignant disorder involving periodontal sites. J. Periodontol. 2009, 80, 274-281. [CrossRef]

14. Poveda-Roda, R.; Bagan, J.; Jimenez-Soriano, Y.; Diaz-Fernandez, J.; Gavalda-Esteve, C. Retinoids and proliferative verrucous leukoplakia (PVL). A preliminary study. Med. Oral Patol. Oral Cir. Bucal 2009, 15, e3-e9. [CrossRef] [PubMed]

15. Gouvêa, A.F.; Santos-Silva, A.R.; Speight, P.M.; Hunter, K.; Carlos, R.; Vargas, P.A.; De Almeida, O.P.; Lopes, M.A. High incidence of DNA ploidy abnormalities and increased $\mathrm{Mcm} 2$ expression may predict malignant change in oral proliferative verrucous leukoplakia. Histopathology 2013, 62, 551-562. [CrossRef] [PubMed]

16. Garcia-Chias, B.; Casado-De La Cruz, L.; Esparza-Gomez, G.; Cerero-Lapiedra, R. Diagnostic criteria in proliferative verrucous leukoplakia: Evaluation. Med. Oral Patol. Oral Cir. Bucal 2014, 19, e335-e339. [CrossRef] [PubMed]

17. Flores, I.L.; Santos-Silva, A.R.; Della Coletta, R.; Leme, A.F.P.; Lopes, M.A. Low expression of angiotensinogen and dipeptidyl peptidase 1 in saliva of patients with proliferative verrucous leukoplakia. World J. Clin. Cases 2016, 4, 356-363. [CrossRef] [PubMed]

18. Garcia-Pola, M.J.; Llorente-Pendas, S.; Gonzalez-Garcia, M.; Garcia-Martin, J.M. The development of proliferative verrucous leu-koplakia in oral lichen planus. A preliminary study. Med. Oral Patol. Oral Cir. Bucal 2016, 21, e328-e334. [CrossRef]

19. Borgna, S.C.; Clarke, P.T.; Schache, A.G.; Lowe, D.; Ho, M.W.; McCarthy, C.E.; Adair, S.; Field, E.A.; Field, J.K.; Holt, D.; et al. Management of proliferative verrucous leukoplakia: Justification for a conservative approach. Head Neck 2017, 39, 1997-2003. [CrossRef]

20. Thomson, P.J.; Goodson, M.L.; Smith, D.R. Potentially malignant disorders revisited-The lichenoid lesion/proliferative verrucous leukoplakia conundrum. J. Oral Pathol. Med. 2018, 47, 557-565. [CrossRef]

21. Upadhyaya, J.D.; Fitzpatrick, S.G.; Islam, M.N.; Bhattacharyya, I.; Cohen, D.M. A Retrospective 20-Year Analysis of Proliferative Verrucous Leukoplakia and Its Progression to Malignancy and Association with High-risk Human Papillomavirus. Head Neck Pathol. 2018, 12, 500-510. [CrossRef] [PubMed]

22. Bagan, J.; Murillo-Cortes, J.; Leopoldo-Rodado, M.; Sanchis-Bielsa, J.M.; Bagan, L. Oral cancer on the gingiva in patients with proliferative leukoplakia: A study of 30 cases. J. Periodontol. 2019, 90, 1142-1148. [CrossRef] [PubMed]

23. Koh, J.; Kurago, Z.B. Expanded Expression of Toll-Like Receptor 2 in Proliferative Verrucous Leukoplakia. Head Neck Pathol. 2019, 13, 635-642. [CrossRef]

24. Favia, G.; Capodiferro, S.; Limongelli, L.; Tempesta, A.; Maiorano, E. Malignant transformation of oral proliferative verrucous leukoplakia: A series of 48 patients with suggestions for management. Int. J. Oral Maxillofac. Surg. 2020, 50, 14-20. [CrossRef]

25. Llorens, C.; Soriano, B.; Trilla-Fuertes, L.; Bagan, L.; Ramos-Ruiz, R.; Gamez-Pozo, A.; Peña, C.; Bagan, J.V. Immune expression profile identification in a group of proliferative verrucous leukoplakia patients: A pre-cancer niche for oral squamous cell carcinoma development. Clin. Oral Investig. 2020, 25, 2645-2657. [CrossRef]

26. McParland, H.; Warnakulasuriya, S. Lichenoid morphology could be an early feature of oral proliferative verrucous leukoplakia. J. Oral Pathol. Med. 2020, 50, 229-235. [CrossRef] [PubMed]

27. Robinson, J.K.; Dellavalle, R.P.; Bigby, M.; Callen, J.P. Systematic reviews: Grading recommendations and evidence quality. Arch. Dermatol. 2008, 144, 97-99. [CrossRef] [PubMed]

28. Abadie, W.M.; Partington, E.J.; Fowler, C.B.; Schmalbach, C.E. Optimal Management of Proliferative Verrucous Leukoplakia: A Systematic Review of the Literature. Otolaryngol. Head Neck Surg. 2015, 153, 504-511. [CrossRef]

29. Torrejon-Moya, A.; Jané-Salas, E.; López-López, J. Clinical manifestations of oral proliferative verrucous leukoplakia: A systematic review. J. Oral Pathol. Med. 2020, 49, 404-408. [CrossRef] [PubMed]

30. Pentenero, M.; Meleti, M.; Vescovi, P.; Gandolfo, S. Oral proliferative verrucous leucoplakia: Are there particular features for such an ambiguous entity? A systematic review. Br. J. Dermatol. 2014, 170, 1039-1047. [CrossRef] [PubMed]

31. Bagan, J.V.; Jiménez-Soriano, Y.; Diaz-Fernandez, J.M.; Murillo-Cortés, J.; Sanchis-Bielsa, J.M.; Poveda-Roda, R.; Bagan, L. Malignant transformation of proliferative verrucous leukoplakia to oral squamous cell carcinoma: A series of 55 cases. Oral Oncol. 2011, 47, 732-735. [CrossRef] [PubMed]

32. Bouquot, J.E. Oral verrucous carcinoma: Incidence in two US populations. Oral Surg. Oral Med. Oral Pathol. Oral Radiol. Endodontol. 1998, 86, 318-324. [CrossRef] 
33. Rajendran, R.; Varghese, I.; Sugathan, C.K. Ackerman's tumour (verrucous carcinoma) of the oral cavity: A clinicepidemiological study of 426 cases. Aust. Dent. J. 1988, 23, 295-298. [CrossRef]

34. Ackerman, L.V. Verrucous carcinoma of the oral cavity. Surgery 1948, 23, 670-678.

35. Bagan, J.; Murillo-Cortes, J.; Poveda-Roda, R.; Leopoldo-Rodado, M.; Bagan, L. Second primary tumors in proliferative verrucous leukoplakia: A series of 33 cases. Clin. Oral Investig. 2019, 24, 1963-1969. [CrossRef] [PubMed]

36. Slaughter, D.; Southwick, H.; Smejkal, W. Field cancerization in oral stratified squamous cell carcinoma: Clinical implications of multicentric origins. Cancer 1953, 6, 963-968. [CrossRef]

37. Braakhuis, B.J.M.; Tabor, M.P.; Kummer, J.A.; Leemans, C.R.; Brakenhoff, R.H. A genetic explanation of Slaughter's concept of field cancerization: Evidence and clinical implications. Cancer Res. 2003, 63, 1727-1730. [PubMed]

38. Simple, M.; Suresh, A.; Das, D.; Kuriakose, M.A. Cancer stem cells and field cancerization of Oral squamous cell carcinoma. Oral Oncol. 2015, 51, 643-651. [CrossRef]

39. Gopalakrishnan, R.; Weghorst, C.M.; Lehman, T.A.; Calvert, R.J.; Bijur, G.; Sabourin, C.L.; Mallery, S.R.; Schuller, D.E.; Stoner, G.D. Mutated and wild-type p53 expression and HPV integration in proliferative verrucous leukoplakia and oral squamous cell carcinoma. Oral Surg. Oral Med. Oral Pathol. Oral Radiol. Endodontol. 1997, 83, 471-477. [CrossRef]

40. Palefsky, J.M.; Silverman, S., Jr.; Abdel-Salaam, M.; Daniels, T.E.; Greenspan, J.S. Association between proliferative verrucous leukoplakia and infection with human papillomavirus type 16. J. Oral Pathol. Med. 1995, 24, 193-197. [CrossRef] [PubMed]

41. Campisi, G.; Giovannelli, L.; Ammatuna, P.; Capra, G.; Colella, G.; Di Liberto, C.; Gandolfo, S.; Pentenero, M.; Carrozzo, M.; Serpico, R.; et al. Proliferative verrucous vs. conventional leukoplakia: No significantly increased risk of HPV infection. Oral Oncol. 2004, 40, 835-840. [CrossRef] [PubMed]

42. Bagan, J.V.; Jimenez, Y.; Murillo, J.; Gavaldá, C.; Poveda, R.; Scully, C.; Alberola, T.M.; Torres-Puente, M.; Pérez-Alonso, M. Lack of association between proliferative verrucous leukoplakia and human papillomavirus infection. J. Oral Maxillofac. Surg. 2007, 65, 46-49. [CrossRef] [PubMed]

43. Axell, T.; Holmstrup, P.; Kramer, J.R.; Pindborg, J.J.; Shear, M. International seminar on oral leukoplakia and associated lesions re-lated to tobacco habits. Commun. Dent. Oral Epidemiol. 1984, 12, 145-154. [CrossRef]

44. Akrish, S.; Ben-Izhak, O.; Sabo, E.; Rachmiel, A. Oral squamous cell carcinoma associated with proliferative verrucous leukoplakia compared with conventional squamous cell carcinoma-A clinical, histologic and immunohistochemical study. Oral Surg Oral Med. Oral Pathol. Oral Radiol. 2015, 119, 318-325. [CrossRef] [PubMed] 